Relations industrielles

Industrial Relations

\title{
Anne Hill and Mark R. Killingsworth (Ed.), Comparable Worth: Analyses and Evidence
}

\section{Morley Gunderson}

Volume 46, numéro 1, 1991

URI : https://id.erudit.org/iderudit/050654ar

DOI : https://doi.org/10.7202/050654ar

Aller au sommaire du numéro

Éditeur(s)

Département des relations industrielles de l'Université Laval

ISSN

0034-379X (imprimé)

1703-8138 (numérique)

Découvrir la revue

Citer ce compte rendu

Gunderson, M. (1991). Compte rendu de [Anne Hill and Mark R. Killingsworth (Ed.), Comparable Worth: Analyses and Evidence]. Relations industrielles /

Industrial Relations, 46(1), 225-226. https://doi.org/10.7202/050654ar

Tous droits réservés @ C Département des relations industrielles de l'Universite Laval, 1991
Ce document est protégé par la loi sur le droit d'auteur. L'utilisation des services d'Érudit (y compris la reproduction) est assujettie à sa politique d'utilisation que vous pouvez consulter en ligne.

https://apropos.erudit.org/fr/usagers/politique-dutilisation/ 
Le livre se termine par une discussion des stratégies patronales possibles pour l'implantation de l'équité.

Ce livre est constitué comme un dossier qui présente aux employeurs ce qu'ils doivent absolument savoir avant de s'embarquer dans un processus d'implantation de l'équité salariale. À ce titre, et compte tenu des particularités des lois américaines, il ne peut vraiment servir qu'aux employeurs américains, sauf peut-être les chapitres 5 et 6 qui sont plus techniques et qui traitent de l'évaluation des emplois dans le contexte de l'équité. On peut cependant déplorer à ce sujet l'exemple retenu par Patten (le plan Hay): on n'y retrouve pas certains facteurs (par exemple, la simultanéité des tâches) reconnus comme caractéristiques de beaucoup d'emplois féminins. Ce qui devrait inciter à la prudence dans la considération de plan semblable pour l'atteinte de l'équité salariale. Enfin, l'auteur ne traite pas de l'impact important de l'organisation du travail sur les écarts salariaux: il considère que la rémunération à la performance par exemple, est compatible avec la notion de travail équivalent (p. 2).

En résumé, ce livre pourra sans doute être utile aux employeurs américains à qui il est destiné de toute façon mais il comporte certaines lacunes qui découlent d'une définition étroite de la discrimination et qui nous amènent à nous interroger sur le standard d'équité qui y est véhiculé.

Esther DÉOM

Université Laval

Comparable Worth: Analyses and Evidence, edited by M. Anne HiLl and Mark R. Killingsworth, Ithaca, ILR Press, New York State School of Industrial and Labour Relations, Cornell University, 1989, 138 p., ISBN 0-87546-147-6. - ISBN 0-87546-148-4 (pbk.)

With all jurisdictions in Canada, except for the three Western provinces, having some form of pay equity legislation (i.e., equal pay for work of equal value), there should be considerable interest in quality research on the topic. This volume, which is the product of a colloquium held at Rutgers University in 1987, is an important contribution in that regard.

The colloquium was an "all-star" cast of paper writers and discussants, from a number of disciplines, albeit economists tended to dominate. The papers were a judicious blend of theory and policy analysis, as well as empirical evidence, usually with due attention paid to the existing literature. In fact the summaries of the relevant theoretical and empirical literature on different aspects of the topic, were extremely useful.

The first paper, by Mark Aldrich and Robert Buchele, examined the implications of efficiency wages for comparable worth. (Comparable worth is the term used in the United States for equal pay for work of equal value.) Efficiency wages refer to wages paid above the competitive norm. They have an efficiency rationale in that they may improve effort, morale, commitment, loyalty and productivity, and they may reduce turnover, shirking and conflict. Efficiency wages will tend to be paid in jobs where these attributes are important, for example where turnover costs are high. Women may be excluded from such jobs because of discrimination or because of a perception that they may have greater turnover. The authors provide empirical evidence from the U.S. indicating that the greatest potential for comparable worth is in industry that pay large wage premiums. They also indicate, however, that there are few women in those sectors to benefit by a comparable worth policy that compels the sharing of those wage premiums. 
Joyce Jacobson provides a neoclassical economic critique of comparable worth, highlighting that even if many of the unrealistic assumptions of the competitive model are dropped, comparable worth leads to inefficiencies and adverse employment effects. She also argues that it does not receive high grades as a policy to achieve equity or fairness, in part because such concepts are often illdefined.

Elaine Sorensen provides a critical review of the theoretical and empirical literature on the relationship between the sex composition of an occupation and wages - and ultimately the male-female wage gap. She highlights the problems with the data and empirical procedures used in most studies and provides some new evidence that takes account of many of these problems. She finds that the pay in jobs held exclusively by women tends to be 23 percent less than the pay in jobs held exclusively by men, even after controlling for productivity-related and industrial differences. This importance of occupational segregation as a determinant of the male-female earnings gap, highlights the substantial potential for comparable worth legislation to reduce that gap.

In the final paper, Ron Ehrenberg reviews the empirical procedures and evidence on the impact of comparable worth, especially on wages and employment. His assessment of the evidence is that comparable worth would have only a modest effect on reducing the overall male-female earnings gap, and it would also have only a small adverse employment effect on females.

Each of the papers were enriched by comments and clarifications from discussants, who also often added new material of their own. The editors also provided a concise summary as well as some background material.

While the volume makes an important contribution to the literature, it has a number of shortcomings. First, it could have benefited by a discussion of a number of the implementation and design issues pertaining to such factors as estimating pay lines, adjusting wages, defining the establishment, defining the role of collective bargaining, and allowing exemptions. Second, given the timeliness of the topic, a shorter gap between the conference in 1987 and the publication of the volume in 1989 would have been desirable. Third, the volume would have benefitted by a discussion of Canadian initiatives in this area, given their importance in recent years. We wont claim overt discrimination because our policy initiatives were excluded - just unintended systemic discrimination! Fortunately, these shortcomings are vastly outweighed by the strengths of the book.

Morley GUNDERSON

University of Toronto

\section{A Secretary and a Cook. Challenging Women's Wages in the Courts of the United States and Britain, by Steven L. WILlBORN, Ithaca, ILR Press, 1989, 214 p., ISBN 0-87546-158-1}

This is the author's second book on the issue of comparable worth or pay equity as it is known in Canada. Willborn's 1986 A Comparable Worth Primer looked at the principle from three different angles - economics, litigation and legislation. This new work provides a detailed comparative study and analysis of two seminal court cases. The author's stated intention is to extrapolate general principles from a microscopic examination of the cases, and in this he succeeds admirably.

The reader will have no doubts about Prof. Willborn's position as an advocate of comparable worth. His strong support for the two complainants, Helen Castrilli, a secretary employed by the State of Washington, and Julia Hayward, the cook of the title, employed by a 